\title{
Predominant Dwellings and Their Neighbourhood Environment Qualities in Port Harcourt Metropolis, Nigeria: An Implication for Planning
}

\author{
Emenike G.C. and Sampson A.P. \\ Department of Geography and Environmental Management, University of Port Harcourt, Choba, Rivers State, \\ Nigeria
}

\begin{abstract}
This study assessed the types and quality of dwelling units and the quality of their neighbourhood environments in Port Harcourt Metropolis, Nigeria. The study population was derived by simple random sampling and the data were obtained with the aid of a questionnaire. A total of 920 copies of questionnaire were administered but 891 copies of the questionnaire were returned for further analysis. The findings reveal that overcrowding, poor quality housing, lack of internal facilities and neighbourhood amenities were major problems that demeaned dwelling quality in Port Harcourt. Also,tenement/rooming houses are the predominant type of dwelling units in the city. The correlation between income and type of house lived was positive and significant $(\mathrm{r}=0.804 ; \mathrm{p}=0.0001)$ while on the relationship between income and satisfaction with the quality of dwellings, the correlation was also positive and significant $(r=0.656 ; p=0.0002)$. Significant variation existed in the quality of dwelling units among residential neighbourhoods $\left(X^{2}=159.63 ; p=0.001\right)$.However, the study recommended that the socio-economic and industrial activities should be decentralized to control the urban population increase through rural-urban migration. Also, government should ensure that its agencies monitor all approved plans to guarantee compliance with standards.
\end{abstract}

Keywords:-Dwelling units, Housing quality, Neighbourhood, Environment, Port Harcourt Metropolis

\section{INTRODUCTION}

Developing countries are experiencing a rapid rate of urban growth. This is manifested more in Africa where cities are currently undergoing an urban transition at an unprecedented scale and pace; with an estimated population growth rate of 5\% per year, the proportion of African's urban residents double every 15 years (United Nations, 2002), while it is estimated that by the year 2020 the urban population would reach $68 \%$ (Opuenebo, 2007). The Universal Declaration of Human Rights enshrined in Article 25 of the UN General Assembly in 1948 affirms the right to adequate housing as a vital part of human rights (Habitat for Humanity, 2014). Subsequently, section 16(1) (d) of the 1999 Constitution of the Federal Republic of Nigeria puts the government under responsibility "to provide suitable and adequate shelter for all citizens". Unfortunately, greater population of this country has not enjoyed this right by any exercise and this is evident in the poor conditions of housing for greater number of urban dwellers which according to Ogunleye (2013) are clearly an affront to human dignity. Consequently, the incidence of this population in urban centers has created severe housing problems, resulting in overcrowding and inadequate dwellings (FGN, 2006, 2012). This coincides with an early report of the World Bank and United Nations Centre for Human Settlement that not less than one billion people in less developed countries (LDCs) live in houses unfit for human habitation and it is anticipated that this number will increase rapidly unless deliberate measures are taken (World Bank/UNCHS, 1990). Waziri and Roosli (2013) noted that dearth of adequate housing virtually abounds in developing and third world countries, though the shortage is in both quantitative and qualitative terms, which is more acute in urban centres. However, it was reported that $87 \%$ of the current supply of housing are backlogs and do not meet the minimum quality in terms of design, functionality and acceptability (Jibrin, 2009 in Kabir and Bustani, 2012). Not surprisingOmojimi (2000) notedthat people that sleep in indecent houses in the Nigerian urban cities outnumbers people who sleep in decent houses.

Conceivably, a major trait of housingcrisis notable in urban centres in most developing nations is that of inadequate supply relative to demand (Olotuah, 2000; Arayela, 2003), while affordability remains an insurmountable challenge (Ogu and Ogbuozobe, 2001 in Adejumo, 2008) despite a number of new policies, programs and strategies being engaged in by public and private sectors in addressing this problem (Ibem et al., 2011). Numerous studies on the adequacy and quality of dwellings both in Nigeria and beyond are evident (Ebong, 1983; Bryne et al., 1986; Olotuah, 2000; Ogonor, 2002; Coker et al., 2007, Nubi, 2008; Wokekoro and Owei, 2014). Coker et al. (2007) investigated the challenges of urban housing quality in relation to their 
neighbourhood environments in Ibadan City and found that in both high, medium and low density areas most houses in the city of Ibadan are classified as unfit for human habitation, overcrowded, generally lack basic facilities and lacked in good maintenance culture. This they noted is a major cause of the decline in housing quality. Similarly, studies by Ogonor (2002) and Wokekoro and Owei (2014) assessed housing problems and planning implications, and residential quality of life in Port Harcourt metropolis respectively, as measures of evaluating qualitative dwellings and reported that dwellings lack basic housing amenities with most of their components worn and torn, while drainages are blocked and waste disposed improperly. Ogonor (2002) also reported absence of cross ventilation; and that gutters that provide drainage are being filled up, especially with various forms of waste matter; which makes the blocked drains incubators for mosquitoes and subsequently affect the health of residents (Wokekoro and Owei, 2014).

However, all these studies revealed that income is a major determinant of housing choice. While, this may stand in its own right, other variables such as cultural orientation, indigenous factors, heritage, nearness to work and high profit business sites are also indomitable factors that influence dwellers choice of dwellings. There is also dearth of information about room size/dimension that would accentuate the recommended occupancy ratio of two persons per room. Again, inadequate attention is being given to the types of houses lived in especially in Port Harcourt Metropolis. It is against these backdrops that this study assessed the degree of variation in types and quality of dwelling units and their neighbourhoods environmental conditions in Port Harcourt Metropolis, Rivers State, Nigeria.

\section{METHODOLOGY}

The descriptive survey design was adopted for this study. The data for this study were obtained from primary and secondary sources. The primary sources of data emanated from direct observations, questionnaire instrument and field works. The secondary data were obtained from existing literature and institutional publications such as those of the National Population Commission (1991, 1996, 2006 and 2012). Accordingly, the reliability of the instrument was established by the use of test-retest technique and yielded a coefficient value of 0.99 after correlating the scores with Pearson Product Moment Correlation Coefficient. The target population of this study comprised the residential neighbourhoods in Port Harcourt metropolis which comprised of Port Harcourt City Local Government Area (PHALGA) and Obio/AkporLocalGovernment Area(OBALGA). PHALGA consists of 25 communities while OBALGA consists of 89 communities making a total of 114 communities (National Population Commission, 1991, 1996, 2006 and 2012; Rivers State Central Statistical Agency (RSCSA), 2003). Out of these, 10\% of each of the sample frame (that is 3 communities from PHALGA and 8 from Obio/Akpor) was selected as the sample via the simple random sampling technique using lottery method, which gave a total of eleven (11) communities used for the study. The study locations included Nkpolu/Oroworukwo (parts of mile 3 Diobu) (C1), Elelenwo (C2), Orije (Old GRA) (C3), Rumuepirikom (C4), Choba (C5), Rukpokwu (C6), Orominike (D-Line) (C7), Eliozu (C8), Rukpakwolusi (C9), Agip Estate (C10) and Iwofe (C11). The total projected population for the 11 communities selected was 218,956which consisted of 36,494 households. These were finally reduced to achieve the actual sample size by applying the Taro Yamane (1967) formula to the household population of each of the communities which yielded a total of 920 copies of questionnairewhichwere administered in proportion to the population of each community whereby only 891 copies of the questionnaire were returned and used for the analysis.Descriptive and inferential statistics were used for the analysis. Pearson's Product Moment Correlation statistics was used to determine the significant relationship between income and choice of dwelling units while analysis of variance was used to determine the spatial variation in the quality of dwelling units among residential neighbourhoods. Statistical Package for the Social Sciences (SPSS) 20.0 Version was used for the analysis.

\section{Predominant types of dwelling units in Port Harcourt}

\section{RESULTS AND DISCUSSION}

The result in Table 1 reveal that $26 \%$ of the entire population representing majority lives in tenement/rooming houses; $25 \%$ live in detached bungalows; $23 \%$ live in semi-detached bungalows while $11 \%$ live in duplexes. $9 \%$ live in blocks of flats and $6 \%$ live in batchers and other makeshift or squalid settlements. Hence, tenement/rooming houses are the prevalent type of house in Port Harcourt metropolis and they are predominantly found in Nkpolu/Oroworukwo, Elelenwo, Rumuepirikom, Choba, Rukpoku, Eliozu and Rukpakwolusi axes. A reason for this may be the fact that these are indigenous enclaves/settlements in addition to being densely populated, hosts the lower class and the houses cheaper to afford. Also, Nkpolu has the highest number of shanties. 
Table 1: Predominant Types of Dwelling Units Lived in Port Harcourt

\begin{tabular}{|l|l|l|l|l|l|l|l|l|l|l|l|l|l|}
\hline $\begin{array}{l}\text { Community } \\
\text { Responses }\end{array}$ & C1 & C2 & C3 & C4 & C5 & C6 & C7 & C8 & C9 & C10 & C11 & Frequency & $\%$ \\
\hline $\begin{array}{l}\text { Detached } \\
\text { Bungalow }\end{array}$ & 50 & 4 & 21 & 34 & 30 & 12 & 56 & 4 & 2 & 3 & 6 & 222 & 25 \\
\hline $\begin{array}{l}\text { Semi-Detached } \\
\text { Bungalow }\end{array}$ & 56 & 10 & 17 & 17 & 30 & 7 & 60 & 3 & 2 & 0 & 2 & 204 & 23 \\
\hline $\begin{array}{l}\text { Tenement/ } \\
\text { Rooming } \\
\text { House }\end{array}$ & 62 & 17 & 17 & 23 & 39 & 18 & 44 & 6 & 4 & 3 & 1 & 234 & 26 \\
\hline Blocks of Flat & 20 & 5 & 10 & 10 & 14 & 4 & 10 & 3 & 0 & 1 & 0 & 77 & 9 \\
\hline Duplex & 39 & 7 & 19 & 12 & 4 & 2 & 13 & 2 & 0 & 1 & 0 & 99 & 11 \\
\hline Shanty/Batcher & 27 & 5 & 2 & 2 & 9 & 2 & 6 & 0 & 1 & 0 & 1 & 55 & 6 \\
\hline TOTAL & 254 & 48 & 86 & 98 & 126 & 45 & 189 & 18 & 9 & 8 & 10 & 891 & 100 \\
\hline
\end{tabular}

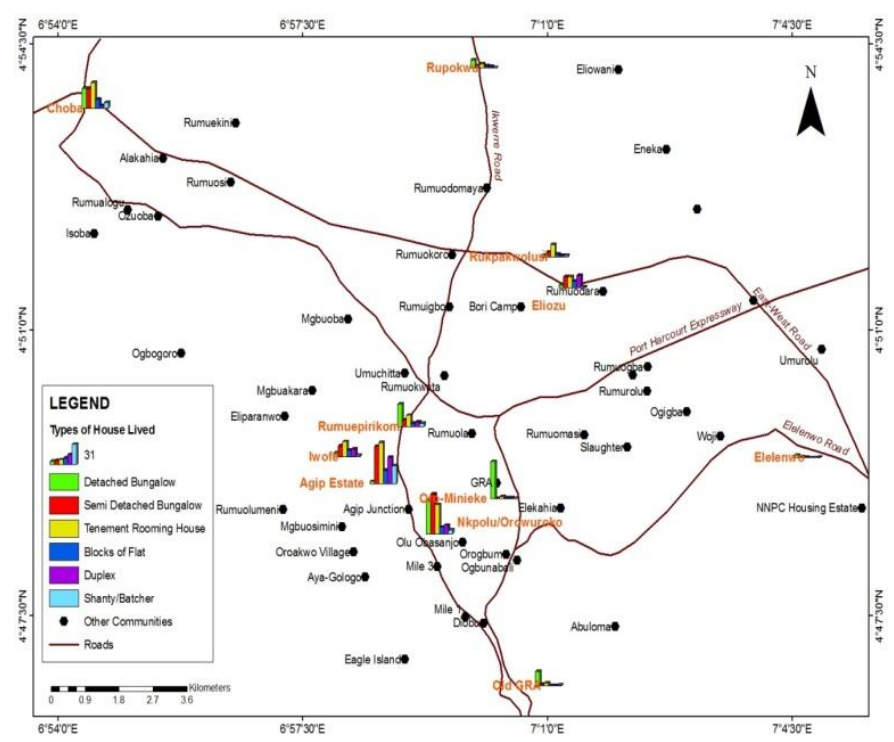

Figure1: Types of houses lived in Port Harcourt Metropolis

\section{Internal Facilities in the houses lived}

It is indicated in the analysis in Table 2 that only $38 \%$ of the entire population has access to electricity implying that a larger proportion of the entire sampled households representing $62 \%$ lack electricity supply in their homes; while only $14 \%$ of them have water supply indicating that majority covering $86 \%$ do not have water supply; and only $30 \%$ have parking lots implying that majority constituting $70 \%$ lack parking spaces. The result also indicates that $26 \%$ do not have toilets; $25 \%$ do not have kitchen and $28 \%$ lack bathroom. Some of these are similar to the findings of Toyobo et al. (2011) and Wokekoro and Owei (2014). This lack of electricity supply has aided the patronage of power generating sets locally called "I Pass My Neighbour" which in turn proves to be a major source of noise and air pollution. The non-availability of parking lots in the houses is responsible for the indiscriminate and notorious parking of vehicles along the streets of the city.

Table 2: Internal Facilities in the Houses lived

\begin{tabular}{|l|l|l|l|l|l|l|l|l|l|l|l|l|l|}
\hline $\begin{array}{l}\text { Community } \\
\text { Responses }\end{array}$ & $\mathrm{C} 1$ & $\mathrm{C} 2$ & $\mathrm{C} 3$ & $\mathrm{C} 4$ & $\mathrm{C} 5$ & $\mathrm{C} 6$ & $\mathrm{C} 7$ & $\mathrm{C} 8$ & $\mathrm{C} 8$ & $\mathrm{C} 10$ & $\mathrm{C} 11$ & $\begin{array}{l}\text { Total } \\
\text { freq }\end{array}$ & $\%$ \\
\hline Electricity & 62 & 18 & 50 & 49 & 40 & 25 & 67 & 8 & 5 & 7 & 10 & 341 & 38 \\
\hline Toilet & 205 & 32 & 84 & 61 & 85 & 31 & 133 & 12 & 4 & 7 & 8 & 662 & 74 \\
\hline Kitchen & 218 & 30 & 84 & 63 & 90 & 38 & 115 & 13 & 6 & 6 & 9 & 672 & 75 \\
\hline Bathroom & 209 & 31 & 84 & 61 & 83 & 33 & 109 & 12 & 6 & 6 & 9 & 643 & 72 \\
\hline $\begin{array}{l}\text { Pipe Borne } \\
\text { Water }\end{array}$ & 20 & 2 & 25 & 7 & 11 & 4 & 47 & 0 & 2 & 5 & 3 & 126 & 14 \\
\hline Parking Lot & 35 & 6 & 82 & 42 & 23 & 12 & 54 & 4 & 2 & 4 & 2 & 266 & 30 \\
\hline
\end{tabular}

Facilities in Toilet/Bathroom

The analysis in Table 3 reveal that 507 respondents out of the 891 which nstitutes $57 \%$ have water closets (WCs) 
in their toilets; 143 of them representing $16 \%$ have water heater in the bathrooms; 311 covering $35 \%$ have washing basins; 365 of them which is equivalent to $41 \%$ have shower; 166 of them representing $19 \%$ have bath tub; and 101 respondents constituting $11 \%$ have none of the above facilities.

Table 3: Facilities in Toilet/Bathroom

\begin{tabular}{|l|l|l|l|l|l|l|l|l|l|l|l|l|l|}
\hline $\begin{array}{l}\text { Community } \\
\text { Responses }\end{array}$ & C1 & C2 & C3 & C4 & C5 & C6 & C7 & C8 & C9 & C10 & C11 & $\begin{array}{l}\text { Total } \\
\text { freq }\end{array}$ & $\%$ \\
\hline Water Closet & 120 & 28 & 74 & 50 & 62 & 14 & 131 & 10 & 6 & 4 & 8 & 507 & 57 \\
\hline Heater & 41 & 3 & 38 & 5 & 11 & 6 & 14 & 2 & 1 & 4 & 4 & 143 & 16 \\
\hline $\begin{array}{l}\text { Washing } \\
\text { Basin }\end{array}$ & 96 & 17 & 69 & 28 & 21 & 16 & 46 & 3 & 4 & 4 & 7 & 311 & 35 \\
\hline Shower & 101 & 19 & 78 & 43 & 53 & 27 & 14 & 14 & 5 & 4 & 7 & 365 & 41 \\
\hline Bath Tub & 48 & 4 & 57 & 11 & 14 & 3 & 15 & 2 & 2 & 4 & 6 & 166 & 19 \\
\hline None & 25 & 7 & 0 & 8 & 28 & 11 & 18 & 1 & 1 & 1 & 1 & 101 & 11 \\
\hline
\end{tabular}

\section{Household Size}

Table 4 reveals that household population of 4-6 persons has highest score of $41 \%$ while those of 1-3 persons scored $36 \%$. Households whose populations are 7-9 persons constituted $16 \%$ and those that are 10 persons and above $7 \%$.

Table 4: Household Size

\begin{tabular}{|l|l|l|l|l|l|l|l|l|l|l|l|l|l|}
\hline $\begin{array}{l}\text { Community } \\
\text { Responses }\end{array}$ & C1 & C2 & C3 & C4 & C5 & C6 & C7 & C8 & C9 & C10 & C11 & $\begin{array}{l}\text { Total } \\
\text { freq }\end{array}$ & $\%$ \\
\hline $1-3$ persons & 95 & 8 & 26 & 39 & 45 & 17 & 82 & 4 & 2 & 3 & 1 & 322 & 36.14 \\
\hline 4-6 persons & 92 & 25 & 42 & 50 & 32 & 23 & 80 & 11 & 6 & 4 & 5 & 370 & 41.53 \\
\hline $7-9$ persons & 43 & 9 & 15 & 5 & 35 & 4 & 20 & 3 & 1 & 1 & 3 & 139 & 15.60 \\
\hline 10 \& above & 24 & 6 & 3 & 4 & 14 & 1 & 7 & 0 & 0 & 0 & 1 & 60 & 6.73 \\
\hline TOTAL & 254 & 48 & 86 & 98 & 126 & 45 & 189 & 18 & 9 & 8 & 10 & 891 & 100 \\
\hline
\end{tabular}

\section{Number of rooms/units occupied by households}

From table 5 it is shown that respondents who occupy one room and two rooms units represented $30 \%$ respectively. Those who occupy three rooms $22 \%$, four rooms scored a total $11 \%$ and those occupying five rooms and above represented 7\%. If the prevalent household sizes in table 4 are matched with the prevalent number of rooms occupied in table 5, it implies overcrowding in the dwellings. The implication of overcrowded households is that there will be not enough space for the household members' comfort plus overbearing on the internal housing facilities, which in turn leads to unprecedented wear and tear of the facilities. Overcrowding sharply negate the recommended standard of 2 persons per room. While these recommended standards are commendable and corroborated, it is salient to opine that occupancy ratio should be subject to and hugely reliant on the size of the room. Thus, to determine how many persons to live in a room, recourse must be given to the dimension or size of the room. This is because a room of small dimension will definitely undermine the recommendation of 2 persons per room and will be a potential source of discomfort to its inhabitants be it a single occupant. Although, Emenike (1999) in an earlier study noted that caution should be exercised when considering the issue of overcrowding since an average Nigerian views accommodating relatives as more of hospitality than inconvenience.But this in our opinion is an "ethno-psycho orientation" which may not represent the true feelings of the situation, as we observed in this study that socio-economic factors such as desire for nearness to urban choices and opportunities, poverty, unemployment and the high cost of qualitative housing are driving forces of overcrowding in these circumstances.

Table 5:Number of Rooms/Units Occupied by Households

\begin{tabular}{|l|l|l|l|l|l|l|l|l|l|l|l|l|l|}
\hline $\begin{array}{l}\text { Community } \\
\text { Responses }\end{array}$ & $\mathrm{C} 1$ & $\mathrm{C} 2$ & $\mathrm{C} 3$ & $\mathrm{C} 4$ & $\mathrm{C} 5$ & $\mathrm{C} 6$ & $\mathrm{C} 7$ & $\mathrm{C} 8$ & $\mathrm{C} 9$ & $\mathrm{C} 10$ & $\mathrm{C} 11$ & $\begin{array}{l}\text { Total } \\
\text { freq }\end{array}$ & $\%$ \\
\hline One Room & 67 & 20 & 24 & 32 & 33 & 22 & 56 & 4 & 3 & 1 & 4 & 266 & 30 \\
\hline
\end{tabular}




\begin{tabular}{|l|l|l|l|l|l|l|l|l|l|l|l|l|l|}
\hline Two Rooms & 65 & 17 & 21 & 30 & 36 & 10 & 70 & 8 & 5 & 2 & 2 & 266 & 30 \\
\hline Three Rooms & 56 & 8 & 27 & 13 & 34 & 7 & 38 & 4 & 1 & 2 & 3 & 193 & 22 \\
\hline Four Rooms & 41 & 3 & 7 & 14 & 17 & 6 & 12 & 2 & 0 & 0 & 0 & 102 & 11 \\
\hline Five \& Above & 25 & 0 & 7 & 9 & 6 & 0 & 13 & 0 & 0 & 3 & 1 & 64 & 7 \\
\hline TOTAL & 254 & 48 & 86 & 98 & 126 & 45 & 189 & 18 & 9 & 8 & 10 & 891 & 100 \\
\hline
\end{tabular}

\section{External amenities provided in the housing neighbourhoods}

Table 6 shows that a smaller proportion of the total number of respondents representing $39 \%$ of the population has street lights in their neighbourhoods; also, greater number of respondents which constitutes $54 \%$ of the population held that their neighbourhood roads are not tarred, $46 \%$ indicate that theirs are paved/tarred; majority of the respondents representing $74 \%$ of the population do not have access to public water supply, while $24 \%$ have access to public water supply; majority of the population representing $49.38 \%$ do not have drainages in their housing neighbourhoods, while $48.26 \%$ have drainages in their environment; only $38.7 \%$ of the population are provided with waste disposal units; $14.6 \%$ have access to recreation facilities; $26 \%$ have access to health care facilities; $37.3 \%$ have access to police station; $45 \%$ have shopping facilities; only $4.5 \%$ have all of the neighbourhood facilities; while $8 \%$ held that none of the neighbourhood amenities exist in their housing environment.

Table 6: External amenities provided in the housing neighbourhoods

\begin{tabular}{|l|l|l|l|l|l|l|l|l|l|l|l|l|l|}
\hline $\begin{array}{l}\text { Community } \\
\text { Responses }\end{array}$ & CI & C2 & C3 & C4 & C5 & C6 & C7 & C8 & C9 & C10 & C11 & $\begin{array}{l}\text { Total } \\
\text { Freq }\end{array}$ & $\%$ \\
\hline Street lights & 124 & 0 & 53 & 26 & 58 & 5 & 70 & 3 & 5 & 2 & 3 & 349 & 39 \\
\hline $\begin{array}{l}\text { Paved/tarred } \\
\text { roads }\end{array}$ & 109 & 2 & 70 & 29 & 44 & 22 & 124 & 3 & 3 & 2 & 4 & 412 & 46 \\
\hline Public water & 64 & 0 & 32 & 41 & 33 & 7 & 36 & 1 & 1 & 0 & 0 & 215 & 24 \\
\hline Drainage & 118 & 0 & 65 & 50 & 45 & 16 & 117 & 2 & 4 & 8 & 5 & 430 & 48.26 \\
\hline $\begin{array}{l}\text { Waste } \\
\text { disposal } \\
\text { units }\end{array}$ & 109 & 0 & 55 & 26 & 37 & 12 & 102 & 0 & 1 & 2 & 1 & 345 & 38.7 \\
\hline $\begin{array}{l}\text { Recreation } \\
\text { facilities }\end{array}$ & 24 & 0 & 45 & 20 & 18 & 2 & 21 & 0 & 0 & 0 & 0 & 130 & 14.6 \\
\hline $\begin{array}{l}\text { Health care } \\
\text { facilities }\end{array}$ & 35 & 1 & 46 & 36 & 34 & 14 & 59 & 1 & 1 & 3 & 2 & 232 & 26 \\
\hline $\begin{array}{l}\text { Police } \\
\text { Station }\end{array}$ & 107 & 2 & 56 & 48 & 45 & 12 & 53 & 3 & 1 & 1 & 4 & 332 & 37.3 \\
\hline $\begin{array}{l}\text { Shopping } \\
\text { Facilities }\end{array}$ & 182 & 8 & 21 & 39 & 61 & 26 & 58 & 1 & 1 & 2 & 2 & 401 & 45 \\
\hline $\begin{array}{l}\text { All of the } \\
\text { above }\end{array}$ & 12 & 0 & 20 & 7 & 1 & 0 & 0 & 0 & 0 & 0 & 0 & 40 & 4.5 \\
\hline $\begin{array}{l}\text { None of the } \\
\text { above }\end{array}$ & 12 & 43 & 0 & 6 & 4 & 0 & 0 & 0 & 0 & 0 & 0 & 68 & 8 \\
\hline
\end{tabular}

\section{Factors influencing the choice of dwelling units and neighbourhoods}

Table 7 reveal that majority of the dwellers covering $40 \%$ chose to live in their present dwellings and neighbourhoods because of their income status and affordability capacity; $23 \%$ do so because the dwellings and neighbourhoods are their homes of origin; $12 \%$ expressed that their preference for their present dwellings is because of nearness to their work/businesses; $5 \%$ held that it is because they found the dwellings conducive; $6 \%$ held that there reason is due to availability of amenities; while $4.7 \%$ gave free rental as their reason. Another $5 \%$ held that it is because of easy accessibility and $4 \%$ due to security concern.

Table 7: Determinants of choice of dwelling units and Neighbourhoods

\begin{tabular}{|l|l|l|l|l|l|l|l|l|l|l|l|l|l|}
\hline $\begin{array}{l}\text { Community } \\
\text { Responses }\end{array}$ & C1 & C2 & C3 & C4 & C5 & C6 & C7 & C8 & C9 & C10 & C11 & $\begin{array}{l}\text { Total } \\
\text { freq }\end{array}$ & $\%$ \\
\hline $\begin{array}{l}\text { Home of } \\
\text { Origin }\end{array}$ & 58 & 12 & 3 & 31 & 35 & 20 & 33 & 6 & 5 & 1 & 4 & 208 & 23 \\
\hline
\end{tabular}




\begin{tabular}{|l|l|l|l|l|l|l|l|l|l|l|l|l|l|}
\hline $\begin{array}{l}\text { Income/Rental } \\
\text { Affordability }\end{array}$ & 118 & 20 & 23 & 37 & 49 & 16 & 74 & 10 & 3 & 4 & 4 & 358 & 40 \\
\hline $\begin{array}{l}\text { Nearness to } \\
\text { work/Business }\end{array}$ & 28 & 9 & 7 & 10 & 16 & 6 & 27 & 2 & 1 & 2 & 2 & 110 & 12 \\
\hline Free Rental & 10 & 5 & 3 & 6 & 7 & 3 & 8 & 0 & 0 & 0 & 0 & 42 & 5 \\
\hline $\begin{array}{l}\text { Conducive } \\
\text { Place }\end{array}$ & 8 & 0 & 19 & 0 & 3 & 0 & 18 & 0 & 0 & 0 & 0 & 48 & 5 \\
\hline $\begin{array}{l}\text { Availability of } \\
\text { Amenities }\end{array}$ & 12 & 2 & 13 & 4 & 8 & 0 & 11 & 0 & 0 & 0 & 0 & 50 & 6 \\
\hline Accessibility & 10 & 0 & 10 & 4 & 5 & 0 & 15 & 0 & 0 & 0 & 0 & 44 & 5 \\
\hline Security & 10 & 0 & 8 & 6 & 3 & 0 & 3 & 0 & 0 & 1 & 0 & 31 & 4 \\
\hline Total & 254 & 48 & 86 & 98 & 126 & 45 & 189 & 18 & 9 & 8 & 10 & 891 & 100 \\
\hline
\end{tabular}

Dwellers Perception on satisfaction with their present dwelling units and rating of the quality of dwelling and neighbourhoods

Table 8 reveal that greater proportion of the population representing $55 \%$ is not satisfied with their dwellings while $45 \%$ expressed satisfaction with their dwellings. The second part of the tablealsoreveals that the majority of the population representing $33.9 \%$ rated the quality of their dwellings and neighbourhood environment as poor, $31.8 \%$ rated theirs as average; $18.7 \%$ rated theirs as good; $7.9 \%$ rated theirs as very good and $7.7 \%$ indicated that theirs is very poor. Significant variation existed in the quality of dwelling units among residential neighbourhoods $\left(\mathrm{X}^{2}=159.63 ; \mathrm{p}=0.001\right)$ (Table 9).

Table 8:Dwellers Perception on satisfaction with their present dwelling units and rating of the quality of dwelling and neighbourhoods

\begin{tabular}{|l|l|l|l|l|l|l|l|l|l|l|l|l|l|}
\hline $\begin{array}{l}\text { Community } \\
\text { Responses }\end{array}$ & C1 & C2 & C3 & C4 & C5 & C6 & C7 & C8 & C9 & C10 & C11 & $\begin{array}{l}\text { Total } \\
\text { freq }\end{array}$ & $\%$ \\
\hline Yes & 120 & 19 & 59 & 38 & 60 & 15 & 75 & 4 & 4 & 4 & 4 & 402 & 45 \\
\hline No & 134 & 29 & 27 & 60 & 66 & 30 & 114 & 14 & 5 & 4 & 6 & 489 & 55 \\
\hline Total & 254 & 48 & 86 & 98 & 126 & 45 & 189 & 18 & 9 & 8 & 10 & 891 & 100 \\
\hline & & & & & & & & & & & & & \\
\hline $\begin{array}{l}\text { Rating of } \\
\text { the quality } \\
\text { of } \\
\text { dwellings }\end{array}$ & C1 & C2 & C3 & C4 & C5 & C6 & C7 & C8 & C9 & C10 & C11 & $\begin{array}{l}\text { Total } \\
\text { freq }\end{array}$ & $\%$ \\
\hline Very Poor & 35 & 9 & 0 & 0 & 5 & 1 & 18 & 0 & 1 & 0 & 0 & 69 & 7.7 \\
\hline Poor & 92 & 24 & 8 & 44 & 50 & 11 & 58 & 8 & 0 & 1 & 6 & 302 & 33.9 \\
\hline Average & 70 & 12 & 25 & 28 & 34 & 21 & 68 & 8 & 7 & 6 & 4 & 283 & 31.8 \\
\hline Good & 38 & 3 & 40 & 13 & 29 & 10 & 30 & 2 & 1 & 1 & 0 & 167 & 18.7 \\
\hline Very Good & 19 & 0 & 13 & 13 & 8 & 2 & 15 & 0 & 0 & 0 & 0 & 70 & 7.9 \\
\hline TOTAL & 254 & 48 & 86 & 98 & 126 & 45 & 189 & 18 & 9 & 8 & 10 & 891 & 100 \\
\hline
\end{tabular}

Table 9: Chi square analysis

\begin{tabular}{|l|r|r|r|}
\hline & \multicolumn{1}{|c|}{ Value } & df & $\begin{array}{c}\text { Asymp. Sig. (2- } \\
\text { sided) }\end{array}$ \\
\hline Pearson Chi-Square & 159.627 & 40 & 0.001 \\
\hline Likelihood Ratio & 177.319 & 40 & 0.001 \\
\hline Linear-by-Linear Association & 1.606 & 1 & 0.205 \\
\hline N of Valid Cases & 778 & & \\
\hline
\end{tabular}

\section{Income per annum of respondents}

Table 10 shows that income of $\$ 216,000$ and below per annum are greater in number representing $46 \%$. Those who earn $\$ 217,000$ - $\$ 400,000$ represent $12 \%$, $\$ 601,000$ - $\$ 800,000$ constitute $11 \%$ while $\$ 401,000$ to $\$ 600,000$ and $\$ 801,000-\$ 1,000,000$ represent $10 \%$ each. $\$ 1,000,000$ and above earners represent $6 \%$. 3\% do not earn income and $4 \%$ did not disclose their income. 
Table 10: Income per Annum (

\begin{tabular}{|l|l|l|l|l|l|l|l|l|l|l|l|l|l|}
\hline $\begin{array}{l}\text { Community } \\
\text { Responses }\end{array}$ & C1 & C2 & C3 & C4 & C5 & C6 & C7 & C8 & C9 & C10 & C11 & $\begin{array}{l}\text { Total } \\
\text { freq }\end{array}$ & $\%$ \\
\hline $\begin{array}{l}216, \quad 000 \text { and } \\
\text { below }\end{array}$ & 119 & 22 & 14 & 52 & 88 & 4 & 100 & 2 & 2 & 1 & 3 & 407 & 45.7 \\
\hline $\begin{array}{l}217, \quad 000-400, \\
000\end{array}$ & 27 & 0 & 8 & 8 & 24 & 3 & 29 & 5 & 1 & 1 & 0 & 106 & 11.9 \\
\hline $\begin{array}{l}401,000-600, \\
000\end{array}$ & 24 & 8 & 3 & 7 & 7 & 2 & 28 & 4 & 3 & 1 & 0 & 87 & 9.8 \\
\hline $\begin{array}{l}601, \\
000\end{array}$ & 20 & 10 & 22 & 8 & 6 & 6 & 16 & 3 & 0 & 2 & 2 & 95 & 10.7 \\
\hline $\begin{array}{l}801,800, \\
1,000,000\end{array}$ & 9 & 3 & 15 & 3 & 0 & 6 & 9 & 2 & 1 & 2 & 3 & 53 & 5.9 \\
\hline $\begin{array}{l}1,000,000 \\
\text { above }\end{array}$ & 16 & 0 & 0 & 8 & 0 & 0 & 0 & 0 & 1 & 0 & 0 & 25 & 2.8 \\
\hline None & 25 & 0 & 0 & 0 & 0 & 8 & 0 & 0 & 0 & 0 & 0 & 33 & 3.7 \\
\hline No Response & 254 & 48 & 86 & 98 & 126 & 45 & 189 & 18 & 9 & 8 & 10 & 891 & 100 \\
\hline TOTAL & & & & & & & & & & & \\
\hline
\end{tabular}

Relationship between income per annum of dwellers and type of house lived and satisfaction of dwelling units

The relationship between the income of Port Harcourt dwellers and choice of dwelling unit is shown in Table 11 . The correlation between income and type of house lived was positive and significant $(\mathrm{r}=0.804 ; \mathrm{p}=0.0001)$. Considering the relationship between income and satisfaction with the quality of dwellings, the correlation was also positive and significant $(\mathrm{r}=0.656 ; \mathrm{p}=0.0002)$. So we conclude that there is significant relationship between income and satisfaction with the quality of dwelling.

Table 11: Relationship between income and type of house being lived and satisfaction with the quality of dwelling

\begin{tabular}{|l|c|r|r|r|}
\hline & \multicolumn{3}{|c|}{ Income per annum } \\
\hline & $\begin{array}{c}\text { Correlation } \\
(\mathrm{r})\end{array}$ & r square & $\begin{array}{c}\text { Coefficient } \\
\text { of } \\
\text { determination }\end{array}$ & $\mathrm{p}$ value \\
\hline $\begin{array}{l}\text { Type of house } \\
\text { being lived }\end{array}$ & $0.804^{* *}$ & 0.6464 & $64.6 \%$ & 0.0001 \\
\hline $\begin{array}{l}\text { Satisfaction } \\
\text { with the } \\
\text { quality of } \\
\text { dwelling }\end{array}$ & $0.656^{* *}$ & 0.4303 & $43.0 \%$ & 0.0002 \\
\hline
\end{tabular}

**. Correlation is significant at the 0.01 level (2-tailed).

\section{CONCLUSION AND RECOMMENDATIONS}

Generally, the result of the study show that major housing and environmental problems in Port Harcourt metropolis include shortage of decent dwellings, high cost of housing, overcrowding, lack of pipe borne (portable) water, poor waste disposal and management, high noise level, blocked drainages, lack or epileptic power supply, poor road condition. These findings are similar to those of Ogonor (2002), Wokekoro (2005) and Wokekoro and Owei (2014). Majority of the population that aspire and/or wish to relocate from their current dwellings notwithstanding the kind of tenure they enjoy in the dwellings would do so because they desire better dwelling implying that they are dissatisfied with their dwellings. The mixed uses to which residential buildings are put especially the commercial and quasi-industrial uses within same residential dwellings are a major source of discomfort to dwellers. Notable among these is the high and unbearable noise generated by power plants and other process machines. Many dwellers live in their present residents for reasons other than income status.Based on the findings of the study, it is recommended that holistic review of existing housing policies must be done in order to address the present realities and make candid foreordainment for the future in terms of housing adequacy, functionality, standard and quality and must as such consider them the core. The socio-economic and industrial activities should be decentralized to control the urban population increase through rural-urban migration. Government should ensure that its agencies monitor all approved plans 
to guarantee compliance with standards. Finally, required authorities should carryout routine inspection on residential houses to ensure compliance to standards.

\section{REFERENCES}

[1] A.A Adejumo,Some Thoughts on Affordable and Social Housing in Nigeria", Retrieved from http://www.nigeriavillagesquare.com/articles/akintokunbo-a-adejumo/some-thoughts-on-affordable-andsocial-housing. 2008.

[2] O. Arayela, Panacea for increasing housing stock at reduced cost in Nigeria. African Journal of Development Studies, 3(1) 2003, 12-16.

[3] D.S. Bryne, S.P. Harrison, J. Keithley and P. McCarthy, "Housing and Health: The relationship between housing conditions and the health of council tenants", Gower, England, 1986, 149P.

[4] A.O. Coker, O.S. Awokola, P.O. Olomolaiye, and C.A. Booth, Challenges of Urban Housing Quality and Its Associations with Neighbourhood Environments: Insights And Experiences Of Ibadan City, Nigeria,Chartered Institute of Environmental Health, Volume: 7 Issue:1.2007.

[5] M.O. Ebong, The Perception of Residential Quality: A case study of Calabar, Nigeria. Third World Planning Review, 5(3):1983, 273-284

[6] G.C. Emenike, Housing in Adeyemo and Oyegun (Eds.) 1999, Port Harcourt Region, Paragraphics, Km7 Air Force Shops, Mancet Junction, PH-Aba Expressway, Port Harcourt, 1999.

[7] Federal Government of Nigeria (1999) Constitution of the Federal Republic of Nigeria as Amended.

[8] Federal Government of Nigeria, National Policy on Housing presented at the Federal University of Technology, Akure. 2006.

[9] Federal Government of Nigeria, "National Policy on Housing as adopted 2012."

[10] Habitat for Humanity, The Six Dimensions of Housing Adequacy, New Zealand, http://www.habitat.org.nz/about/dimensions.html. 2014.

[11] E.O Ibem,M.N.Anosike, and D.E. Azuh,Challenges in public housing provision in the post-independence era in Nigeria. International Journal of Human Sciences, Volume: 8 Issue: 2, 2011.

[12] B. Kabir, and S.A. Bustani, A Review of Housing Delivery Efforts in Nigeria,Department of Building, Faculty of Environmental Design, Ahmadu Bello University-ZariaNigeria@http://www.gla.ac.uk/media/media_129767_en.pdf.of, 2012.

[13] National Population Commission, National Census Final ResultsProjection based on 2.84\% growth rate with 1991 as base year and 3.4\% from 2006 to 2015. 2012

[14] O.T. Nubi,Affordable Housing Delivery in Nigeria. The South African Foundation International Conference and Exhibition, Cape Town, October, 2008, 1-18.

[15] C.U.M. Ogonor,Housing Problems and Planning Implications in the City of Port Harcourt" in Arokoyu , S. B. and Adeyemo, A. M. (eds.) Perspective on Urban Development Planning and Management, Amethyst and colleagues publishers, Lagos, Nigeria. 2002.

[16] B. M. Ogunleye, (2013): "Analysis of the socio-economic characteristics and housing condition in the core neighbourhood of Akure, Nigeria".Journal of Geography and Regional Planning; Federal University of Technology, Akure, Ondo State, Nigeria. 6(6): 2013, 229-236.

[17] A.O. Olotuah,Housing Low-Income Civil Servants in an Emergent State Capital - the case study of AdoEkiti, Unpublished Ph.D Thesis, Federal University of Technology, Akure, Nigeria. 2000.

[18] I.O. Omojinmi, I. O. SINA Technical Workshop on Housing Co-operatives, Nairobi 6th-17th October. 2000.

[19] O. Opuenebo, Distortions of the Urban Land Markets in Nigerian Cities and the Implications for Urban Growth Patterns: The Case of Abuja and Port Harcourt. Fourth Urban Research Symposium. 2007.

Rivers State Central Statistical Agency (SCSA), Department of Statistics, Manpower and Research, Rivers State Ministry of Budget and Economic Planning (RSMBEP), 1991, 1997-2003 Population Publication. 2003.E. Toyobo, A. B. Muili, and J.O.Ige, Correlates of Socio - economic Characteristics of Housing Quality in Ogbomosho Township. Oyo State, Nigeria. Glob. J. Hum. Soc. Sci. U.S.A. 1(7). 2011.

[20] United Nations Organisation, Universal Declaration of Human Rights adopted and proclaimed by the UN General Assembly in 1948.

[21] A.G. WaziriandR. Roosli, Current Housing Policies and Strategies in Nigeria: A Review of the Concept and Implementation. Society for Business and Management Dynamics, 3(2), 2013, 60-68.

[22] W. Wokekoro, and O.B. Owei, An Assessment of Residential Quality of Life in Old Port Harcourt, Township of Port Harcourt Municipality. International Journal of Science and Research (IJSR) ISSN (Online), 3(2),2014.

[23] World Bank/Habitat, The United Nations Centre for Human Settlement (Habitat). 1990.

[24] T. Yamane, Statistics, an Introductory Analysis, $2^{\text {nd }}$ ed., Harper and Row, New York. 1967. 